\title{
A study of airborne fungal spores of Anyigba, Kogi State, Nigeria
}

\author{
Essien, Benjamin Christopher ${ }^{1}$, Taiga, Akpovughaye ${ }^{1}$, Suleiman, Mohammed Nasirudeen ${ }^{1}$, \\ Idachaba, Stephen Onojo ${ }^{2}$, Aniama, Salome Ojone ${ }^{3}$, Edegbo, Emmanuel ${ }^{4}$ \\ ${ }^{1}$ Department of Biological Sciences, Kogi State University, Anyigba, Nigeria \\ ${ }^{2}$ Department of Biology, Kogi State College of Education, Ankpa, Nigeria \\ ${ }^{3}$ Department of Biology, Federal College of Education, Okene, Nigeria \\ ${ }^{4}$ Department of Microbiology, Kogi State University, Anyigba
}

Email address:

essienbenjamin_jnr@yahoo.com (Essien, B. C.)

\section{To cite this article:}

Essien, Benjamin Christopher, Taiga, Akpovughaye, Suleiman, Mohammed Nasirudeen, Idachaba, Stephen Onojo, Aniama, Salome Ojone, Edegbo, Emmanuel. A Study of Airborne Fungal Spores of Anyigba, Kogi State, Nigeria. American Journal of Biomedical and Life Sciences. Vol. 1, No. 4, 2013, pp. 70-74. doi: 10.11648/j.ajbls.20130104.11

\begin{abstract}
Airborne fungal spores of Anyigba, Dekina Local Government Area, Kogi State, Nigeria during the months of March - December, 2012 were trapped, acetolysed and analysed palynologically to determine the genera of airborne fungal spores and/or particles present in the atmosphere. A total of 9491 fungal spores were counted. The predominant spore types include those of Botryodiplodia, Curvularia, Gliomastix, Drechslera/Helminthosporium, Neurospora, Nigrospora, Pithomyces, Teliospore and Stemphylum. The presence of fungal spores in the atmosphere affirms the great influence of anthropogenic activities on the local vegetation. Analysis of variance for the various airborne fungal spores showed that there was no significant difference $(\mathrm{P}>0.05)$ between the various groups. This study would provide a good template that could be used to monitor the frequency and intensity of fungal allergies and various disease conditions of plants, animals and man in the surrounding Savanna environment, and provide adequate restoration and conservation measures for safety health and environmental sustainability.
\end{abstract}

Keywords: Airborne, Fungal Spores, Bioparticles, Anyigba Environment, Nigeria

\section{Introduction}

Airborne fungal spores are minute, unicellular or multicellular reproductive bodies released into the atmosphere mostly by the action of winds and raindrops. Fungal spores are among the most abundant and least well known airborne allergens in Anyigba. Detailed information concerning their identity and concentration in the air is meager. Only a small fraction of the different fungal spore types are recognizable. Available literatures on studies carried out in Nigeria includeAgwu and Osibe (1992), Agwu (2001), Agwuet al., (2004), and Njokuocha and Osayi (2005).

Fungal spores are of particular interest because of their association with plant diseases and pollinosis in man. They have negative effects on public health, crop survival and yield (Burge and Rogers, 2008). The air quality is known to be affected by the types and concentration of these spores in the atmosphere. Although fungal spores are widely distributed in the atmosphere, investigation shows that they are widely modulated by the prevailing weather condition (Calleja et at., 1993).Fungal spores are cosmopolitan in distribution and constitute a large proportion of the airborne palynomorphs trapped in most aeropalynological studies (Njokuocha and Ukeje, 2006).

Many fungi depend exclusively on wind regime for their spore release and dispersal. This makes it vital to study the seasonal and diurnal periodicities of these airborne fungal spores over a given period (Lyon et al., 1984). The abundance and periodic occurrences of the fungal spore is also affected by the availability of the host plants in the vegetation (Burge and Rogers, 2000).Maize plant and other cereals such as sorghum and millets are common crops cultivated in Anyigba environment. The report of a comprehensive and elaborate aerobiology of this nature in Anyigba environment is almost non- existing.

The main objective of this study was to identify the different airborne fungal spore genera/ types circulating in 
the atmosphere of Anyigba, Kogi State, Nigeria.

\section{Materials and Methods}

\subsection{The Study Area}

Anyigba, Dekina Local Government Area, Kogi State, Nigeria is a university sub-urban town located in the Eastern Senatorial District of the State, Nigeria. The town lies approximately between latitude $7^{0} 30^{1} \mathrm{~N}$ and longitude $7^{0} 15^{1} \mathrm{E}$. It is surrounded by smaller towns, villages and homesteads, whose inhabitants in numerous ways have left their impact on the environment (Fig. 1).

\subsection{Sampling Techniques}

Eight locations were selected within Anyigba, Kogi State, Nigeria as sampling (stations) sites. These sites were chosen for safety and security, logistic reasons and convenience of environmental analysis. At each site, a pollen trap (Modified Tauber Sampler) was buried in the ground in such a way that the collar was about $4 \mathrm{~cm}$ above the ground level (Tauber, 1977).Prior to this, a mixture of glycerol $(65 \mathrm{ml})$, formalin $(30 \mathrm{ml})$ and phenol $(5 \mathrm{ml})$ was poured into each of the trap to prevent the bioparticles from drying up, kill insect and also prevented the decay of dead organisms. The positions of the traps at various locations were noted using a Global Position System (GPS). Twice in a month, solution collection was done and the traps thoroughly washed with water to prevent any contamination, before recharging with the chemical solution. This procedure was repeated bi-monthly from March- December(covering both the dry season sampling and the rainy seasons) for one year.

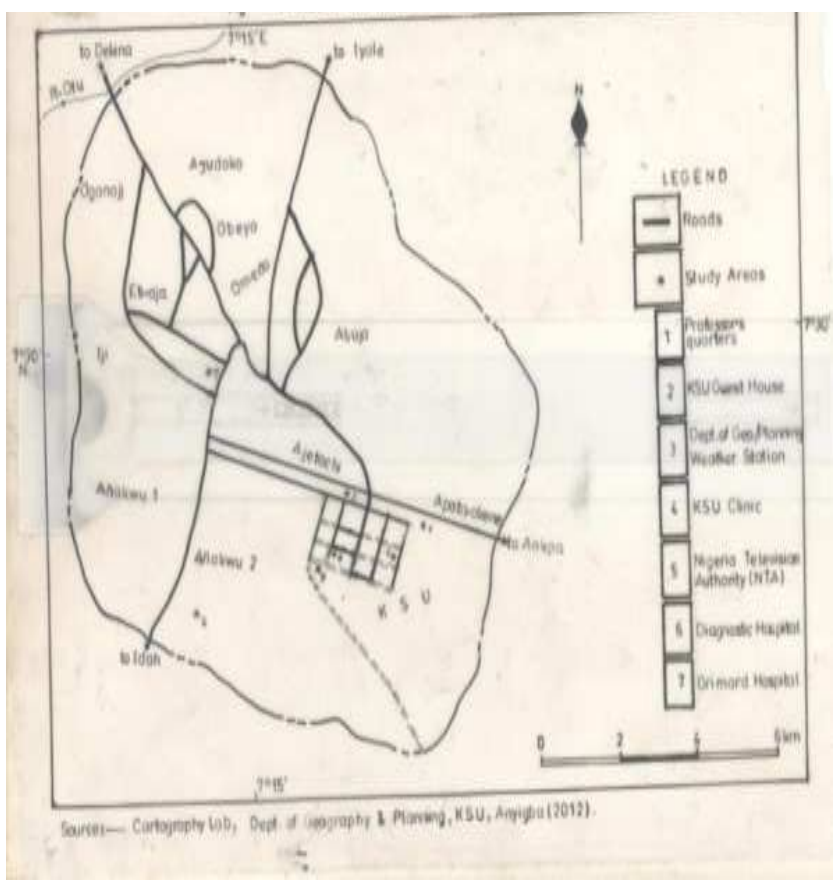

Fig.1 Map of Anyigba showing study areas
The periodic one year bioparticles collected with the pollen samplers were recovered through centrifugation at 2000 r.p.m (revolution per minute) for 5 minutes and supernatant decanted each time. The precipitates were washed twice with distilled water and recovered through centrifugation. The sediments were treated with glacial acetic acid to remove water before acetolysis. Acetolysis mixture was freshly prepared in a ratio of 9:1 from acetic anhydride and concentrated sulphuric acid. Acetolysis was carried out by boiling the bioparticles in a water bath at $100^{\circ} \mathrm{C}$ (Erdtman, 1969; Agwu and Akanbi, 1985). The mixture was placed in water-bath at $100^{\circ} \mathrm{C}$ for 5 minutes, stirred and then centrifuged for 5 minutes and supernatant decanted. The recovered precipitates were washed with glacial acetic acid, and finally washed twice with distilled water, centrifuged each time and decanted. The recovered bioparticles were stored in a plastic vials in glycerin and ethanol solution (2:1).

One drop of thoroughly shaken bioparticles suspension was mounted on microscope slide and covered with an $18 \times 18 \mathrm{~mm}$ cover slip. The mount was sealed off with colorless nail varnish to prevent drying up of the bioparticless. The prepared slides were observed microscopically, bioparticles counted and their morphological details studied. Bioparticles were identified, counted and classified with reference to descriptions and photomicrographs of Agwu and Akanbi (1985); Bonnefille and Riollet (1980); Barnett and Hunter (1998); and Zillinsky (1983).

\section{Results and Discussions}

A total of 9491 fungal spores were trapped with highest in December (1757) and lowest in November(724) (Table 1). Common among fungal spore genera identified include those of Alternaria, Botryodiplodia, Cerastosporium, Curvularia, Exosporium, Gliomastix, Helminthosporium, Neurospora, Nigrospora, Pithomyces, Stemphylium, Syncephalastrum, Teliospore, and Tetraploa (Table 1). Morphological diversity of the predominant fungal spore genera are shown in Fig. 2. The high degree of fungal spore occurrence in the atmosphere is associated with the large traits of maize farms as well as other infected plants in and around Anyigba environment. It is evident to say that several allergic reactions of the eyes resulting in symptoms such as sneezing, runny/ itchy nose as well as itchy and watering eyes prevalent in Anyigba environment is as a result of the abundance and prevalence of different species of these aerospora. This finding agrees favourably with the report of Njokuocha and Ukeje (2006) who opined that fungal spores are cosmopolitan in distribution and constitute a large proportion of the airborne palynomorphs trapped in most aeropalynological studies. Although fungal spores are widely distributed in the atmosphere of Anyigba environment, similar findings in West Africa by Calleja et al., (1993) shows that they are widely modulated by the prevailing weather condition (Table 2). 
Much has been reported about the abundance and cosmopolitan nature of fungal spores and their associated allergenic reactions (runny nose, watery and itchy eye) and diseases of humans, domestic animals and plants. In fact, they constitute very serious danger to immunecompromised patients. Some of the fungal spores identified in this study have been reported by several authors to cause allergies such as rhinitis, pollinosis and exacerbation of asthmatic attack as well as pathogenic infections of the respiratory tract. Some of the spores identified here are among the invasive airborne fungal spores that have been implicated in nosocomial (hospital) infection of patients with solid organ transplants (Richardson and Ellis, 2000; Sanchez and Bush, 2001; Barnes and Rogers, 1989; Cashel et al., (2004). Such spore genera identified include Alternaria, Drechslera/Helminthosporium, Nigrospora and
Curvularia among others.

Pathologically, many fungi species identified in this work have also been associated with diseases of many agricultural crops and wild plants in Nsukka and many other places (Njokuocha, 2006). Among the diseases are loose smut of wheat, maize smut (Ustilago sp.), leaf blight and spots, purple blotch, damping-off and scab caused by species of Alternaria, Drechslera/Helminthosporium, and cassava blight (Alternaria sp.) among others (Adeoti and Marley,1995; Onyeke, et al., 2003; Konopinska, 2004). Most of these fungal pathogens show multiple and whole plant host ranges, while some others are saprophytic on agricultural produce. Their prevalence in the air is a reflection of their entrenchment and serious threats to agricultural crops, their produce as well as wild plants.

Table 1. Concentration of different spore genera trapped from March-December, 2012

\begin{tabular}{|c|c|c|c|c|c|c|c|c|c|c|}
\hline Spores Genera & MAR. & APR. & MAY & JUN. & JUL. & AUG. & NOV. & DEC. & TOTAL & MEAN \\
\hline Alternaria & - & - & 5 & 11 & - & - & 15 & 2 & 33 & 4.125 \\
\hline Botryodiplodia & 22 & 47 & 21 & 8 & 5 & 297 & 34 & 11 & 445 & 55.625 \\
\hline Ceratosporium & 7 & - & - & - & - & - & - & 19 & 26 & 3.25 \\
\hline Curvularia & 630 & 485 & 425 & 450 & 154 & 91 & 205 & 772 & 3212 & 401.5 \\
\hline Exosporium & - & 8 & 2 & 6 & - & - & - & - & 16 & 2 \\
\hline Gliomastix & 14 & 21 & 63 & 46 & 25 & 10 & 33 & 39 & 251 & 31.375 \\
\hline Helminthosporium/Drechslera & 27 & 75 & 20 & 11 & 7 & 5 & 5 & 92 & 242 & 30.25 \\
\hline Neurospora & 65 & 337 & 70 & 41 & - & 11 & 35 & 198 & 757 & 94.625 \\
\hline Nigrospora & 42 & 93 & 3 & 18 & 3 & - & 21 & 16 & 196 & 24.5 \\
\hline Pithomyces & 914 & 146 & 427 & 619 & 611 & 343 & 206 & 475 & 3741 & 467.625 \\
\hline Tetraploa & 22 & 11 & 7 & 4 & - & - & - & - & 44 & 5.5 \\
\hline Teliospore & - & 27 & 27 & - & - & 15 & 79 & 82 & 230 & 28.75 \\
\hline Stemphylum & - & 54 & 38 & 27 & - & 7 & 88 & 30 & 244 & 30.5 \\
\hline Syncephalastrum & 2 & 3 & 5 & 11 & 4 & 5 & 3 & 21 & 54 & 6.75 \\
\hline SUM & 1745 & 1307 & 1113 & 1252 & 809 & 784 & 724 & 1757 & 9491 & 1186.375 \\
\hline
\end{tabular}

Table 2.Mean Monthly Distribution of Climatic Elements over the Environment of the Study Area (2012)

\begin{tabular}{|c|c|c|c|c|c|c|c|c|c|c|c|c|}
\hline PARAMETES & JAN. & FEB. & MAR. & APR. & MAY & JUN. & JUL. & AUG. & SEP & OCT. & NOV. & DEC. \\
\hline Rainfall (mm) & $\begin{array}{l}0.00 \mathrm{~m} \\
\mathrm{~m}\end{array}$ & $\begin{array}{l}0.7 \mathrm{~m} \\
\mathrm{~m}\end{array}$ & $0.0 \mathrm{~mm}$ & $3.7 \mathrm{~mm}$ & $4.0 \mathrm{~mm}$ & $6.1 \mathrm{~mm}$ & $4.4 \mathrm{~mm}$ & $6.2 \mathrm{~mm}$ & $10.3 \mathrm{~mm}$ & $4.3 \mathrm{~mm}$ & $1.2 \mathrm{~mm}$ & $0.0 \mathrm{~mm}$ \\
\hline $\begin{array}{l}\text { Mean } \\
\text { temp. }\left({ }^{\circ} \mathrm{C}\right)\end{array}$ & $\begin{array}{l}20.7 \\
{ }^{\circ} \mathrm{C}\end{array}$ & $\begin{array}{l}23.4 \\
{ }^{\circ} \mathrm{C}\end{array}$ & $25.5^{\circ} \mathrm{C}$ & $24.6^{\circ} \mathrm{C}$ & $23.4^{\circ} \mathrm{C}$ & $22.7^{\circ} \mathrm{C}$ & $21.9^{\circ} \mathrm{C}$ & $21.7^{\circ} \mathrm{C}$ & $21.6^{\circ} \mathrm{C}$ & $21.7^{0} \mathrm{C}$ & $22.3^{0} \mathrm{C}$ & $22.1^{0} \mathrm{C}$ \\
\hline $\begin{array}{l}\text { Relative } \\
\text { humidity (\%) }\end{array}$ & $82.0 \%$ & $84.9 \%$ & $84.7 \%$ & $86.7 \%$ & $81.7 \%$ & $82.2 \%$ & $83.1 \%$ & $82.6 \%$ & $82.1 \%$ & $82.1 \%$ & $81.7 \%$ & $83.8 \%$ \\
\hline $\begin{array}{l}\text { Wind } \\
\text { Direction(W.D) }\end{array}$ & $\mathrm{N} / \mathrm{E}$ & $\mathrm{S} / \mathrm{W}$ & $\mathrm{S} / \mathrm{W}$ & $\mathrm{S} / \mathrm{W}$ & $\mathrm{S} / \mathrm{W}$ & $\mathrm{S} / \mathrm{W}$ & $\mathrm{S} / \mathrm{W}$ & $\mathrm{S} / \mathrm{W}$ & $\mathrm{S} / \mathrm{W}$ & $\mathrm{S} / \mathrm{W}$ & $\mathrm{N} / \mathrm{E}$ & $\mathrm{N} / \mathrm{E}$ \\
\hline $\begin{array}{l}\text { Wind Speed } \\
\text { Km/h (W.S.D) }\end{array}$ & - & - & 4.7 & 4.0 & 3.8 & 3.7 & 4.0 & 3.7 & 4.1 & 3.9 & 3.6 & 4.4 \\
\hline
\end{tabular}

SOURCE: Meteorological Station, Dept. of Geo. \& Planning, Kogi State University, Anyigba(2012) 


\subsection{Photomicrographs of Some Predominant Fungal Spores}

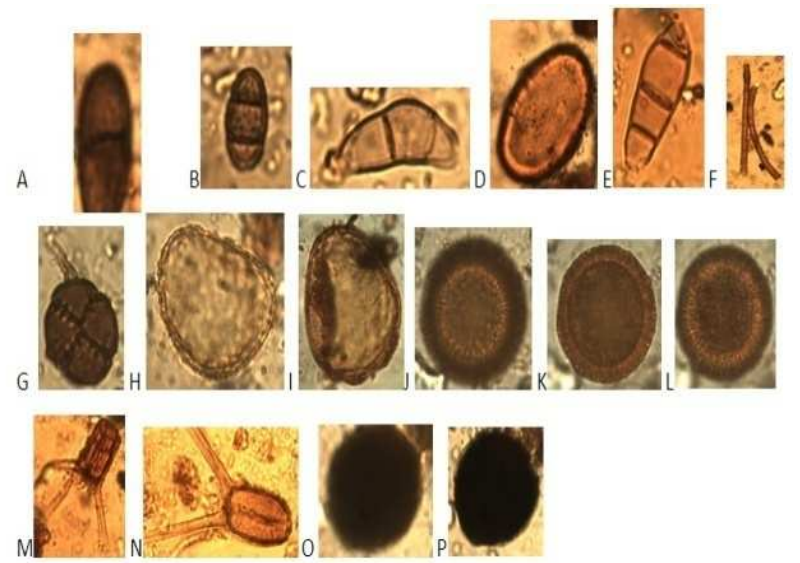

Fig.2 A- P: FUNGAL SPORES: Botryodiplodiatheombromae: $A$ Pithomyces: B; Curvularia: C; Gliomastix: D; Septate fungal hyphae: F. Dictyoarthrinium: G. Monolete spores: H-I; Exosporium: J-L, Tetraploa: $M-N$, Nigrospora: $O-P$

\section{Conclusion}

The study showed that the atmosphere around Anyigba environment contains abundance of fungal spores which are similar and comparable in quantity and quality to the ones identified in other regions which have been found to be associated with the aggravation asthmatic conditions, allergies and various disease conditions of plants, animals and man. This study would provide a good template that could be used to monitor the frequency and intensity of fungal allergies and various disease conditions of plants, animals and man in the surrounding Savanna environment, and provide adequate restoration and conservation measures for safety health and environmental sustainability.

\section{Acknowledgments}

The co-author is grateful to the Almighty God for life, inspiration and resources; his mentor Prof. Ani Essien Nkang and his father in palynology, Prof. Dr. C. O. C. Agwu who introduced, groomed, nurtured and trained him in this special area of plant sciences.

\section{References}

[1] Adeoti, A.A. and Marley, P.S. (1995). Mycoflora associated with cob rots of maize in Samaru, Zaria, northern Nigeria. Nigerian Journal of Botany, 8:57-64.

[2] Agwu, C.O.C. and Akanbi, T.O. (1985). A palynological study ofhoney from four vegetation zones of Nigeria. Pollen et Spores, 27:335-348.

[3] Agwu, C.O.C. and Osibe, E.E. (1992). Airborne Palynomorphs of Nsukka during the months of FebruaryApril, 1990. Nigerian Journal of Botany, 5:177-185.
[4] Agwu, C.O.C. (2001). A Study of Niger Delta Environment through air-borne palynomorphs, Port-Harcourt, Nigeria. Palaeoecology of Africa, 27:191-205.

[5] Agwu, C.O.C., Njokuocha, R.C. and Mezue, O. (2004). The study of airborne pollen and spores circulating at 'head level' in Nsukka environment. Bio-Research, 2(2):7-14.

[6] Barnett, H. L. and Hunter, B. (1998). Illustrated Genera of Imperfect Fungi. Fourth Edition. APS Press, Minnesota, USA. 218pp.

[7] Barnes, R. A. and Rogers, T. R. (1989). Control of an outbreak of nosomialaspergillosis by laminar air-flow isolation. Journal of Hospital infection, 14:89-94.

[8] Bonnefille, R. and Riollet, G. (1980). Pollen des savanna d'Afriqueorientale. Paris: CNRS, 140pp.

[9] Burge, H.A. and Rogers, C.A. (2008). Outdoor Allergens. Environmental Health Perspective, 108-:655-368.

[10] Calleja, M., Strick, R.M. and Duzer, D. (1993). Atmospheric Pollen Content of West Africa. Review of Palaeobotany and Palynology, 79:335-368.

[11] Cashel, P., Newhouse, B. S. and Levetin, E. (2004). Correlation of environmental factors with asthma and rhinitis symptoms in Tulsa, OK. Annals of Allergy, Asthma and Immunology, 92:356-366.

[12] Erdtman, G. (1969). Handbook of Palynology. An introduction to the study of Pollen grains and Spores. Hafnar Publishing Company, New York. 486pp.

[13] Konopinska, A. (2004). Monitoring of Alternaria Ness. And Cladosporium link airborne spores in Lublin (Poland) in 2002. Annals of Agriculture and Environmental Medicine, 11:347-349.

[14] Lyon, F. L., Kramer, C. L. and Eversmeyer, G. M. (1984). Variation in airspora due to weather conditions. Grana, 23: 177- 181 .

[15] Njokuocha, R.C. and Osayi, E.E. (2005). Airborne Pollen Survey in relations to Allergy and Plant pathogens in Nsukka, Nigeria. Nigerian Journal of Biological Research and Biotechnology, 3(1):77-84.

[16] Njokuocha, R. C. and Ukeje, H. O. (2006). The study of airborne pollen precipitation in the University of Nigeria (Nsukka) botanic garden. Bio-Research, 4(2):88-93.

[17] Njokuocha, R. C. (2006). Airborne pollen grains in Nsukka, Nigeria. Grana, 45:73-80.

[18] Onyeke, C. C., Maduewesi, J .N. C. and Ugwoke, K. I. (2003). Incidence of post-harvest fungal diseases of banana (Musa sapientum Linn.) fruits in southeastern Nigeria. Nigerian Journal of Botany, 16:7-15.

[19] Richardson, M.D. and Ellis, M. (2000). Clinical and laboratory diagnosis of systemic fungi infection. Hospital Medicine, 61:61-614.

[20] Sanchez, H. and Bush, R.K. (2001). A review of Alternaria alternate sensitivity Revistaiberoamericana de Micologia, 18:58-59.

[21] Tauber, H. (1977). Investigations of aerial pollen transport in a forested area. Dansk Botanisk Arkiv, 32(1):1-121. 
[22] Zillinsky, F. J. (1983). Common Diseases of Small Grain Cereals. A Guide to Identification. American 